\title{
Obscure Gastrointestinal Bleed from a Gastrointestinal Stromal Tumor in a Jejunal Diverticulum: A Rare Case Report
}

\author{
A. Sadaf D. Sunil B. Athar B. Khalid \\ Department of Surgical Gastroenterology, Sher-e Kashmir Institute of Medical \\ Sciences, Srinagar, India
}

\section{Key Words}

Obscure gastrointestinal bleed · Jejunal diverticulum · Gastrointestinal stromal tumor

\begin{abstract}
We present a case of small bowel diverticulum with gastrointestinal stromal tumor (GIST). This GIST in the diverticulum was confirmed by immunohistochemistry and was of low-grade malignant potential.
\end{abstract}

\section{Case Report}

A 22-year-old woman presented to our department with a history of upper gastrointestinal (GI) bleed in the form of melena of recent onset. She was initially evaluated with upper GI endoscopy and no cause was found. Subsequently, she was subjected to lower GI endoscopy with distal ileal inspection; findings were again normal. Since no cause for the GI bleed was found and due to ongoing minor GI bleed in the form of melena, a repeat upper and lower GI endoscopy was performed by the senior-most endoscopist of the institute, which was again inconclusive. The patient was diagnosed with obscure GI bleed and a CT enteroclysis was planned. A 64-slice CT enteroclysis showed a lesion in relation to the mid small bowel loop, which was highly vascular (fig. 1). A tentative diagnosis of small bowel gastrointestinal stromal tumor (GIST) possibly in a diverticulum was made. The patient was subjected to laparotomy and the extremely rare finding of a mass lesion in a small bowel diverticulum in the distal few centimeters of the jejunum was made. This tumor had a size of $4 \times 4 \mathrm{~cm}$, was highly vascular and located in an antimesenteric diverticulum (fig. 2).

The patient underwent resection of the small bowel with $10-\mathrm{cm}$ margins on either side, along with which a reasonable amount of mesentery was excised (fig. 3 ). The mucosal surface of resected jejunum inspected showed the mouth of the diverticulum (fig. $)$. Histopathological examination of the specimen was suggestive of GIST (fig. 5) in a diverticulum, which was confirmed by electron microscopy and immunohistochemistry. The tumor was graded as low risk GIST. The opinion of a regional cancer society was sought; they did not recommend chemotherapy in view of the low grade of the tumor. 


\begin{tabular}{c|l|l|l}
$\begin{array}{c}\text { Case Reports in } \\
\text { Pintriajy }\end{array}$ & $\begin{array}{l}\text { Case Rep Oncol 2010;3:19-23 } \\
\text { Dol: } 10.1159 / 000274803\end{array}$ & & $\begin{array}{l}\text { Published online: January 13, 2010 S. Karger AG, Basel } \\
\text { ISSN 1662-6575 } \\
\text { www.karger.com/cro }\end{array}$ \\
\hline
\end{tabular}

\section{Discussion}

Small bowel diverticulum or diverticula per se is a rare disease, to conclude from the known actual incidence of symptomatic diverticulum. In many instances, diverticula may be incidentally diagnosed while performing a laparotomy for some other cause. There is a case report suggesting the occurrence of a small bowel diverticulum in 6 out of 8 members of a family [1]. Large bowel diverticulum is more frequent when compared to small bowel diverticulum. Among small bowel diverticulum, false diverticulum is more common, which occurs at a weak point in the bowel wall towards the mesenteric border. True diverticulum (containing all 4 layers of the small bowel wall) is exceptionally rare and occurs at the antimesenteric border. Overall, the incidence of diverticulum reported is $0.06-1.3 \%$ [2]. Diverticulum is also known to be associated with diseases of immunological origin, such as rheumatoid arthritis, ulcerative colitis, and thyroiditis [1]. Symptoms in a diverticulum may be due to occurrence of bacterial overgrowth, inflammation, bleed, mechanical obstruction, or perforation. Rarely, patients may have malabsorption due to multiplicity of mesenteric diverticulum. Bleed in a diverticulum is usually due to inflammatory involvement of the arcade vessel but may rarely occur due to a mass lesion (as in our case) or a vascular malformation [3]. Tumors within a Meckel's diverticulum are uncommon but recognized, with a reported incidence of $0.5-3.2 \%$ [4]. The case presented here is rare since it was a true diverticulum of the jejunum at the antimesenteric border and harbored a GIST.

In the literature, in a series of 8 cases of small bowel diverticulum 7 were not diagnosed preoperatively [5]. Although the role of $\mathrm{CT}$ in the diagnosis of a diverticulum is underestimated, CT enteroclysis, if done with a 64-slice machine, can yield a more accurate diagnosis. As far as a gastrointestinal tumor occurring in a jejunal diverticulum is concerned, it may be the first of its kind in the literature. It is a well-known fact that GISTs are the most common connective tissue tumors of the GI tract, although they are overall rare in occurrence and an estimated incidence is 10-20 cases per million population per year [6]. Approximately 50-70\% of GISTs originate in the stomach. The small intestine is the second most common location, with $20-30 \%$ of GISTs arising from the jejunoileum. Less frequent sites of occurrence include the colon and rectum (5-15\%) and esophagus $(<5 \%)$. The actual cell of origin of GISTs is a pluripotential mesenchymal stem cell programmed to differentiate into the interstitial cell of Cajal [7]. Gain-offunction mutations in exon 11 of the c-kit proto-oncogene are associated with most GISTs. These mutations lead to constitutive overexpression and autophosphorylation of c-Kit, provoking a cascade of intracellular signaling that propels cells toward proliferation or away from apoptotic pathways. Surgery is the definitive therapy for patients with GISTs. Radical and complete surgical extirpation offers the only chance for cure. Debulking large lesions is helpful when adjuvant therapy with imatinib mesylate is considered. Imatinib mesylate (STI 571) is a selective tyrosine kinase inhibitor with action against mutant c-Kit and targets a specific molecular derangement. The role of imatinib in the management of advanced and perforated GISTs is a well established fact. All cases diagnosed to be GISTs need confirmation by immunostaining with CD114, 117 or CD 134; this is the standard procedure accepted all over the world. Only tumors positive for immunostaining respond to treatment with the wonder drug imatinib mesylate.

This particular case has been under follow-up for 9 months and has had no recurrence of symptoms or disease. Due to the tumor's low malignant potential and a tumor size of $<5 \mathrm{~cm}$, chemotherapy with imatinib mesylate was not offered to this patient. 


\begin{tabular}{c|l|l|l}
$\begin{array}{c}\text { Cose Reports in } \\
\text { Oncolady }\end{array}$ & $\begin{array}{l}\text { Case Rep Oncol 2010;3:19-23 } \\
\text { D0I: 10.1159/000274803 }\end{array}$ & Published online: January 13, 2010 & $\begin{array}{l}\text { O 2010 S. Karger AG, Basel } \\
\text { ISSN 1662-6575 } \\
\text { www.karger.com/cro }\end{array}$ \\
\hline
\end{tabular}

Fig. 1. CECT enterocalysis image showing a hyperdense vascular lesion in relation to the small bowel.

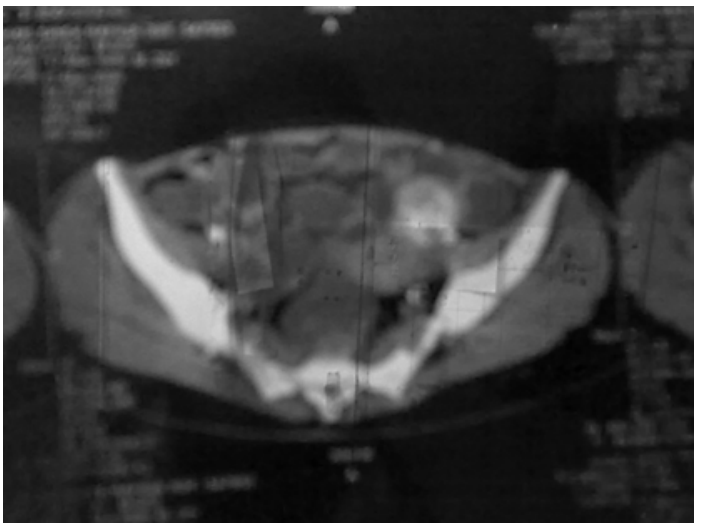

Fig. 2. a, b Note the tumor in a diverticulum at the antimesentric border of the jejunal loop.

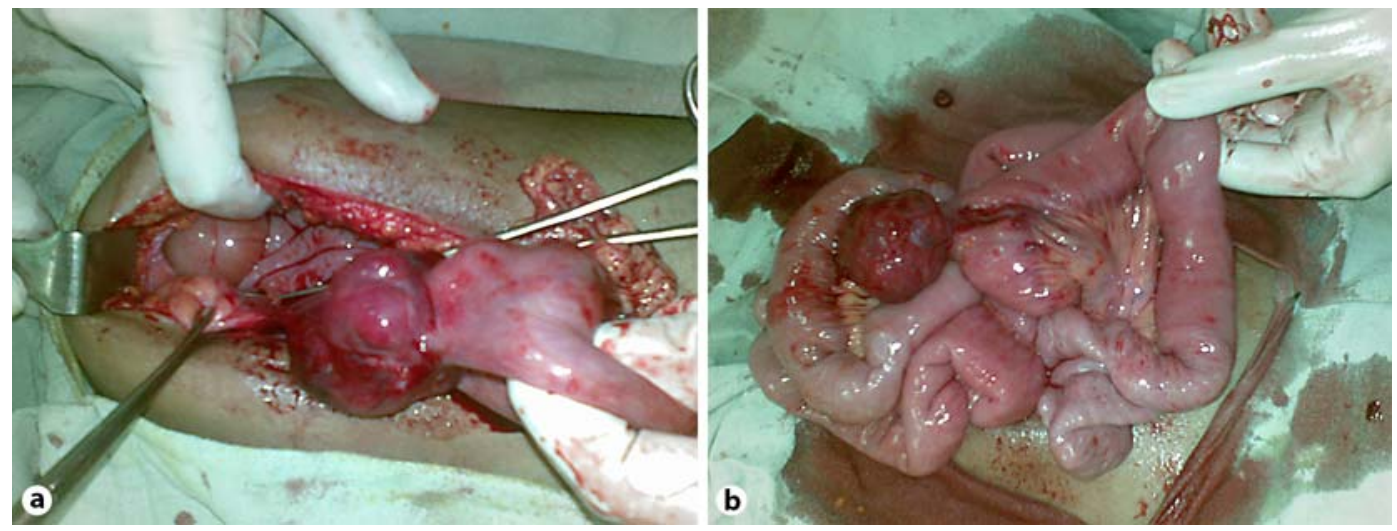

Fig. 3. Resected specimen of the jejenum with tumor.

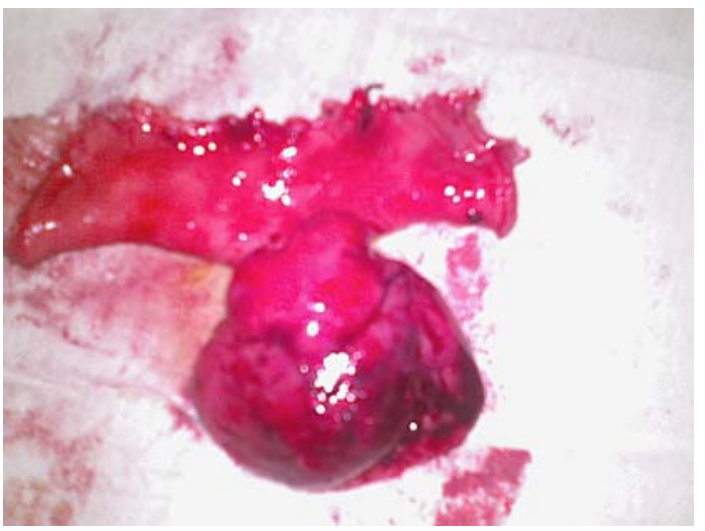




\begin{tabular}{c|l|l|l}
$\begin{array}{c}\text { Cose Reports in } \\
\text { Ondolayy }\end{array}$ & $\begin{array}{l}\text { Case Rep Oncol 2010;3:19-23 } \\
\text { D0I: 10.1159/000274803 }\end{array}$ & Published online: January 13, 2010 & $\begin{array}{l}\text { O 2010 S. Karger AG, Basel } \\
\text { ISSN 1662-6575 } \\
\text { www.karger.com/cro }\end{array}$ \\
\hline
\end{tabular}

Fig. 4. Mucosal surface of the cut specimen showing a dimple-like opening representing the mouth of the diverticulum.

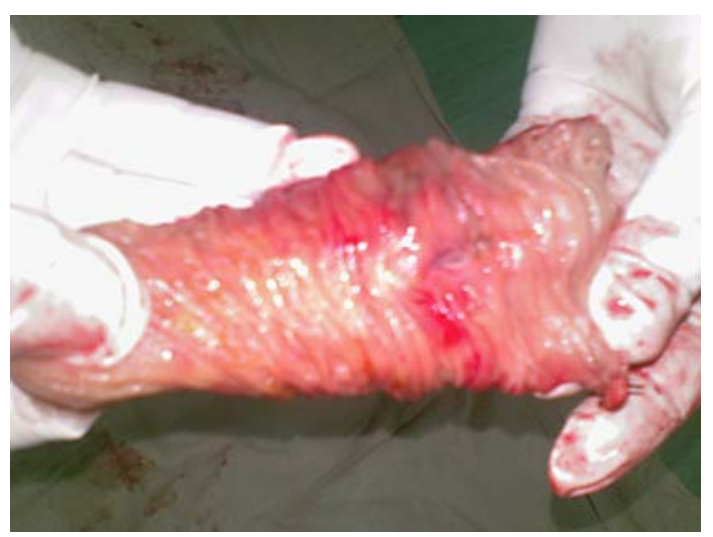

Fig. 5. a-c Histopathological images of the tumor morphology showing predominantly spindle-shaped cells layed in sheats (a); note the uniform eosinophylic cells arranged in short fasicles on high-power evaluation and encircled areas mitotic cells per high-power field (b and $\mathbf{c}$ ).
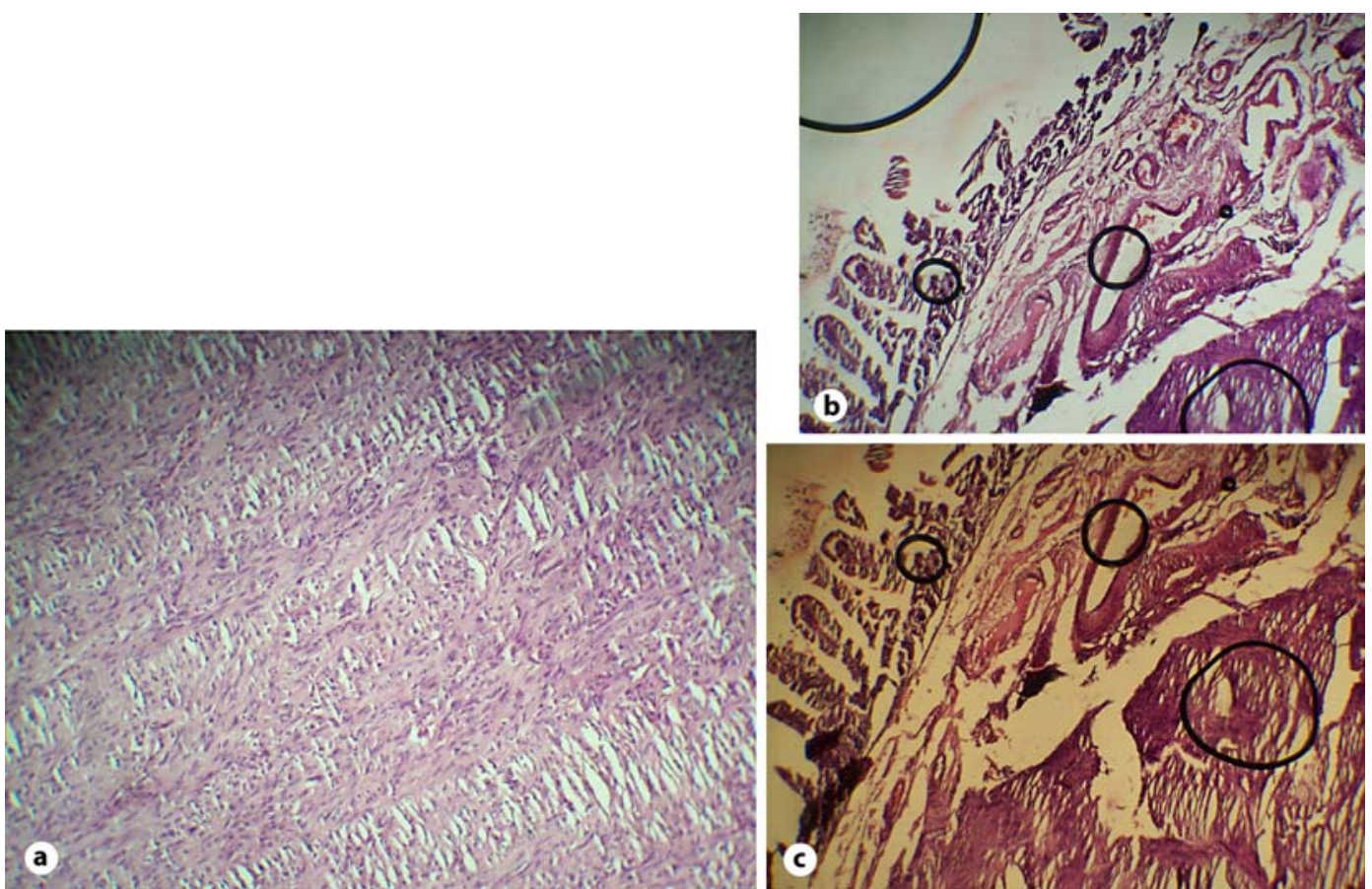


\section{References}

1 Anderson SV, Schjoldager B, Halver B: Jejunal diverticulosis in a family. Scand J Gastroentrol 1988;23:672-674.

2 Koch AD, Schoon EJ: Extensive jejunal diverticulosis in a family, a matter of inheritance? Neth J Med 2007;65:154-155.

-3 Chin NW, Lai CH, Harisiadis SA, Chapman I: Congenital arteriovenous malformation rupturing into a true jejunal diverticulum. Am J Gastroenterol 1989;84:972-974.

-4 Calderdale SM, Marchioni L, Malizia A, Riminucci M, Corsi A: Malignant stromal tumor consistent with fibrosarcoma arising from Meckel's diverticulum. Clinicopathological study of an incidentally discovered tumor and review of the literature. Tumori 1997;83:703-708.

-5 Lempinen M, Salmela K, Kemppainen E: Jejunal diverticulosis: a potentially dangerous entity. Scand J Gastroenterol 2004;39:905-909.

-6 Stamatakos M, Douzinas E, Stefanaki C, et al: Gastrointestinal stromal tumor. World J Surg Oncol 2009;7:61.

-7 Kindblom LG, Remotti HE, Aldenborg F, Meis-Kindblom JM: Gastrointestinal pacemaker cell tumor (GIPACT): gastrointestinal stromal tumors show phenotypic characteristics of the interstitial cells of Cajal. Am J Pathol May 1998;152:1259-1269. 